\title{
KONSISTENSI ANTARA PROGRAM PARTAI DENGAN KEBIJAKAN PUBLIK DI KABUPATEN BANDUNG (2011-2015)
}

\author{
Dede Sri Kartini \\ Rahman Mulyawan \\ Iyep Saefulrahman \\ e-mail: dedesrikartini@yahoo.com
}

\begin{abstract}
ABSTRAK
Visi misi Kepala Daerah terpilih yang pada umumnya diusung oleh partai politik, secara otomatis menjadi visi misi yang nantinya diturunkan ke dalam program-program pemerintah daerah yang bersangkutan selama periode pemerintahannya. Penelitian ini bertujuan untuk mengetahui dan menganalisis konsistensi antara program partai politik Golkar yang mengusung Bupati Kabupaten Bandung periode 2010-2015 dengan program-program pemerintah daerah. Dari penelitian ini diketahui bahwa terdapat misi dari Bupati Kabupaten Bandung yang tidak dapat diturunkan kedalam produk kebijakan publik dalam hal ini Peraturan Daerah dan Peraturan Bupati, selain itu kebijakan-kebijakan pada tahun tertentu tidak mencerminkan aspek pelayanan sebagai salah satu dari fungsi pemerintahan. Program partai belum sepenuhya konsisten dapat diturunkan kedalam kebijakan, karena misi yang dibuat partai belum operasional. Untuk itu, partai pemenang sebaiknya mengawal kebijakan-kebijakan kepala daerahnya.
\end{abstract}

Kata Kunci: Bupati, Partai Politik, Program, Kebijakan.

\section{ABSTRACT}

Vision and mission of elected local heads who are generally promoted by political party, it automatically becomes the vision and mission into the programs of the local government concerned during the period of his duty. This study aims to identify and analyze the consistency between Golkar programs that carries candidate Bandung Regent 2010-2015 period with local government programs. From this research, it is known that there is a mission of the Regent of Bandung which cannot be changed into the products of public policies such as Local Rules and Regen Regulation, besides that, the policies in a certain year do not reflect the aspect of service as one of the functions of government. The party program has not 
been completely consistent yet into the policy, because the mission that made the party has not been yet operational. It is suggestion; the winning party should oversee the policies of the regional head.

Keywords: Head of Regen, Political Party, Program, Policy.

\section{PENDAHULUAN}

Adanya pemilihan kepala daerah langsung sejak tahun 2005 telah memunculkan pergeseran pembuatan kebijakan publik. Sebelum ada pilkada, pembuatan kebijakan murni wilayah suprastruktur tanpa melibatkan rakyat, yaitu hanya Kepala Daerah dan DPRD. Seiring dengan diberlakukannya pilkada, pembuatan kebijakan menjadi melibatkan rakyat melalui kampanye yang disampaikan oleh kandidat. Dalam kampanye tersebut rakyat dapat mengetahui program-program partai politik yang nantinya akan menjadi kebijakan ketika kandidat terpilih berkuasa.

Dalam kampanye, partai politik mengemukakan program-program yang nantinya menjadi kebijakan bila kandidat kelak terpilih. Program yang nantinya menjadi kebijakan pemerintahan inilah yang sering disebut janji kampanye. Menurut Robertson, janji-janji pada saat pemilu inilah yang harus konsisten untuk dilaksanakan ketika kandidat terpilih, sehingga partai politik dipercaya oleh publik ${ }^{111}$.
Konsistensi antara janji kampanye atau program partai dengan produk kebijakan ini sering disebut juga kongruensi. Namun peneliti lebih cenderung untuk menyebut konsistensi dibanding kongruensi, karena kongruensi identik dengan persamaan matematis yang semuanya dihitung serba matematis, sedangkan konsistensi melihat kesesuaian antara program partai dan kebijakan publik yang dapat didekati dengan pendekatan kualitatif. Namun tentunya, ide penelitian ini diilhami oleh penelitian dari Hans-Dieter Klinaemann, Richard I. Hofferbert, dan Ian Budge di sepuluh negara, yaitu Inggris, Australia, Kanada, Prancis, AS, Swedia, Austria, Republik Federal Jerman, Belanda, dan Belgia.

Penelitian Klinaemann dkk., tersebut bertumpu pada suatu kerangka fungsionalis struktural yang memandang partai-partai politik sebagai lembaga yang memainkan dua peranan penting dalam berfungsinya rejim demokratis, yaitu:

Pertama, partai-partai menyeleksi dan merangkum berbagai isu

111 Lihat Klinaemann, dkk., 2000:43. 
serta menyajikannya kepada para pemilih dalam sebuah paket yang kurang lebih runtut, sebagaimana terungkap lewat platform/ manifesto partai. Kedua, partaipartai yang menang menempatkan dirinya sebagai tulang punggung bagi pemerintahan yang terpilih, dengan pengharapan umum bahwa janji-janji kampanye mereka akan diubah menjadi kebijakan publik. ${ }^{112}$

Atas dasar partai politik memainkan dua peran penting tersebut, peneliti ingin melihat konsistensi antara program partai Golkar sebagai pemenang pilkada Kabupaten Bandung tahun 2010 dengan produk kebijakan publik yang dihasilkan oleh kandidat terpilihnya, yaitu pasangan Dadang Naser dan Deden Rukman Rumaji dari tahun 2011 sampai dengan 2015. Rentang waktu ini dipilih untuk menyesuaikan masa jabatan bupati/ wakil bupati Kabupaten Bandung tersebut. Meskipun mereka terpilih pada Oktober 2010 melalui pilkada dua putaran, namun karena ada pengaduan dari kandidat yang diusung PKS ke Mahkamah Konstitusi untuk putaran kedua, maka pasangan ini mulai bekerja tahun 2011 .

Penelitian ini sangat urgen dilakukan karena tidak ada lembaga manapun yang peduli dengan konsistensi capaian kebijakan yang dihasilkan dengan janji kampanye di depan publik. Lembaga-lembaga survei lebih tertarik melihat elektabilitas partai menjelang pemilu, dibanding mengevaluasi realisasi program-program kampanye kepala daerah setelah pemilu. Menurut peneliti, bila kondisi ini dibiarkan kampanye juga tidak akan dipercaya pemilih sehingga akan menyebabkan pemilih apatis ketika pemilu berlangsung, apakah itu pemilu lokal berupa pemilihan gubernur dan walikota/bupati atau pemilu nasional berupa pemilu legislatif maupun pemilu presiden. Padahal untuk memulihkan kepercayaan publik terhadap partai, partai harus merealisasikan janji kampanye atau program partai yang disampaikan kandidat saat pemilu kedalam produkproduk kebijakan publik ketika kandidat terpilih berkuasa.

\section{Rumusan Masalah}

1. Bagaimana visi misi Bupati saat pemilihan pada tahun 2010?

2. Seperti apa produk kebijakan yang telah dikeluarkan selama periode 2011-2015?

3. Bagaimana konsistensi antara program partai Golkar dengan produk kebijakan di Kabupaten Bandung? 


\section{KERANGKA TEORETIS}

Russell J. Dalton dan Martin P. Wattenberg (2000) yang menurunkan pemikiran V.O. Key (1964) tentang salah satu bagian dari kerangka partai politik, menyatakan bahwa salah satu bagian dari kerangka tersebut adalah partai memiliki fungsi di pemerintahan $^{113}$. Pada arena ini, partai bermain dalam pengelolaan dan penstrukturan persoalan-persoalan pemerintahan. Partai telah identik dengan sejumlah aspek kunci proses demokratik.

Terdapat 7 (tujuh) fungsi utama partai di pemerintahan. Pertama, menciptakan mayoritas pemerintahan. Fungsi ini dilakukan setelah pemilihan. Partai-partai yang memperoleh kursi di parlemen dituntut untuk menciptakan mayoritas politik agar, dalam sistem parlementer, dapat membentuk pemerintahan, atau dalam sistem presidensiil, mengefektifkan pemerintahan. Apabila di parlemen tidak ada mayoritas absolute, maka koalisi partai adalah sebuah keniscayaan. Kunci penting terbentuknya formasi koalisiuntukmembentukpemerintahan adalah distribusi sumberdaya partai dan posisi kebijakan partai.

Kedua, pengorganisasian pemerintahan. Pada fungsi ini partai politik menyediakan mekanisme untuk pengorganisasian kepentingan dan menjamin kerjasama di antara individu-individu legislator. Di parlemen, menjadi tanggung-jawab partai untuk mengelola disiplin partai yang itu dapat dilakukan melalui berbagai variasi insentif dan mekanisme kontrol. Partai memonitor legislator dan menegakkan disiplin partai, mengontrol pemilihan kepemimpinan parlemen dan alat kelengkapannya, serta mendistribusikan sumberdaya parlemen kepada legislator.

Ketiga, implementasi tujuan kebijakan. Ketika di pemerintahan, partai politik adalah aktor sentral yang menentukan output kebijakan pemerintahan. Normalnya, pelaksanaan fungsi ini dibentuk dari transformasi manifesto partai dan janji kampanye. Antara manifesto partai atau platform partai dan janji kampanye dengan kebijakan semestinya adalah linier. Ketika berkuasa, partai merealisasikan ketidaksepakatan dan oposisi. Fungsi ini diperankan oleh partai-partai yang tidak menjadi bagian dari penguasa (eksekutif). Partai yang tidak berkuasa membentuk blok politik diluar partai penguasa. Pada fungsi ini, partai oposisi mengembangkan alternative kebijakan diluar kebijakan yang

113 Dalam Pamungkas, 2011. 
ditempuh penguasa. Harapannya, partai oposisi dapat menarik simpati pemilih sehingga di pemilihan berikutnya kekuasaan dapat diambil alih.

Kelima, menjamin tanggungjawab tindakan pemerintah. Adanya partai oposisi menyiratkan kepada siapa tanggung-jawab sebuah pemerintahan harus dibebankan, yaitu partai penguasa. Partai penguasa bertanggung-jawab terhadap berbagai tindakan yang dilakukan pemerintah. Mekanisme ini menjadikan pemilih lebih mudah untuk memberikan kredit atau penghukuman atas keberhasilan dan kegagalan sebuah pemerintahan. Jika pemilih merasa puas dengan kinerja pemerintahan, maka mereka dapat memberikan ganjaran kepada partai penguasa; tetapi apabila pemilih merasa tidak puas, maka suara dapat diberikan kepada partai oposisi.

Keenam, kontrol terhadap administrasi pemerintahan. Fungsi ini terkait dengan peran partai dalam ikut mengontrol birokrasi pemerintahan. Peran itu diwujudkan dalam keterlibatan partai dalam menyeleksi sejumlah individu-individu yang akan menempati jabatan politik tertentu yang sudah disepakati.

Terakhir, ketujuh, adalah memperkuat stabilitas pemerintahan. Stabilitas pemerintahan secara langsung terkait dengan kesatuan partai politik. Stabilitas partai membuat stabil pemerintahan; dan stabilitas pemerintahan berhubungan dengan stabilitas demokrasi. Dalam kerangka itu fungsi partai untuk memperkuat stabilitas pemerintahan dan demokrasi adalah menjaga stabilitas partai. Kesatuan partai politik perlu dipelihara sedemikian rupa agar dapat memperkuat stabilitas pemerintahan.

Ketujuh fungsi di atas menunjukkan bahwa partai penguasa bertanggung-jawab terhadap berbagai tindakan yang dilakukan pemerintah. Tindakan tersebut diwujudkan dengan mengawasi bagaimana kepala daerah terpilih menerjemahkan program partai politik ke dalam programprogram pemerintahannya.

Apabila individu telah menyetujui semua isu-isu partai secara umum, maka ia akan memilih partai tersebut tanpa memperhatikan isu-isu partai lainnya. Isu juga dapat merubah keberpihakan seseorang terhadap partai-seseorang dapat berpindah dari satu partai ke partai lainnya karena melihat isu yang ditampilkan oleh partai lain lebih bagus ${ }^{114}$.

Selain menemukan pilihan politik karena kecintaan terhadap partai, juga kemampuan partai mengembangkan isu-isunya akan sangat berpengaruh

114 Lihat Niemi dan Weisberg, 1984:90. 
pada pilihan. Setiap keterangan, pemberitaan tentang suatu partai oleh media massa akan mampu membentuk opini publik bagi partai yang bersangkutan, sehingga ia selain dikenal karena nama, juga dikenal karena isu atau program yang dinyatakan dan dilakukannya.

Selanjutnya partai akan mengkorversi kepentingan-kepentingan yang ada di masyarakat menjadi program atau isu partai yang ditawarkan melalui kampanye, setelah memegang tampuk pemerintahan maka partai berkewajiban membuat kebijakan-kebijakan berdasarkan program yang sudah ditawarkannya.

Partai-partai lantas mengubah beraneka ragam kehendak itu menjadi isu-isu politik dengan jalanmenyusunsejumlahalternatif kebijakan dengan didasarkan pada prinsip-prinsip umum yang menjadi landasan masingmasing partai. Dengan cara demikianlah partai-partai politik merangkum beragam kehendak menjadi paket-paket kebijakan yang runtut dan longgar - sebuah proses yang menyediakan suatu pilihan bagi para pemilih dalam pemilu. Partai-partai politik membentuk pemerintahan namun juga dapat bertindak sebagai oposisi dalam lembaga legislatif.
Mereka bisa menempati eseloneselon tinggi dalam birokrasi. Maka, partai-partai politik memainkan peranan krusial dalam pengambilan keputusan dan implementasinya ${ }^{115}$.

Partai yang dapat menerjemahkan program kedalam kebijakan publik, menunjukkan kalau partai tersebut memahami fungsinya sebagai artikulasi dan agregasi kepentingan. Ketika kebijakan yang diperjuangkan berhasil diwujudkan, maka penerapan kebijakan publik dilaksanakan dalam suasana yang demokratis.

Seperti yang dikutip Santoso (2010:4-5) dari Budiman, bahwa kebijakan publik merupakan denyut nadi dari proses pemerintahan. Dalam kebijakan, kekuasaan negara bertemu dengan kedaulatan, yang dalam norma demokrasi, dipegang oleh rakyat atau warganegara. Karena dalam rezim negara-bangsa yang saat ini dominan, hanya negara yang memiliki legitimasi untuk membuat sebuah kebijakan publik. Dalam konteks demokrasi, pertanyaan paling mendasar tentang sebuah kebijakan adalah, "seberapa jauh kebijakan pemerintah 'bertaut' dengan kehendak publik warga negara-nya?

115 Lihat Klinaemann, dkk., 2000:9. 
Negara adalah pemegang kekuasaan yang sah. Karena kebijakan publik pada dasarnya adalah kebijakan negara, maka kebijakan publik seringkali diartikan sebagai sebuah tindakan yang dilakukan oleh pemegang kekuasaan untuk memastikan tujuantujuan yang sudah dirumuskan dan disepakati oleh publik bisa tercapai. Oleh karena itu, persoalan kebijakan publik bisa diartikan sebagai persoalan penggunaan kekuasaan. Dalam prakteknya, proses kebijakan berlangsung dalam dinamika relasi antara beragam aktor dengan beragam kepentingan.

Penggunaan kekuasaan yang demokratis akan melahirkan kebijakan publik yang demokratis pula. Kebijakan publik yang demokratis akan memiliki kelebihan sebagai berikut:

... mudah diimplementasikan. Hal ini disebabkan karena dukungan politik (political support) dari kebijakan yang diambil itu kuat, dengan kuatnya dukungan itu maka saat kebijakan diimplementasikan akan sedikit sekali pihak-pihak yang menentangnya, sehingga proses implementasi akan berjalan dengan baik sebab sedikit sekali adanya gangguan ${ }^{116}$.
... akan memiliki basis legitimasi yang kuat. Dengan adanya demokrasidalamsebuahkebijakan publik maka semua elemen dalam masyarakat merasa memiliki atas kebijakan itu. Kebijakan itu mampu mengakomodasi semua kepentingan dan preferensi dalam masyarakat ${ }^{117}$.

Kebijakan dibuat oleh pemerintah yang memenangkan pemilu, sehingga tidak menutup kemungkinan kalau dalam pembuatan kebijakan terdapat tarik-menarik antarberbagai kepentingan.

Kebijakan memang menjadi ranah yang amat berbau kekuatan untuk saling mempengaruhi dan melakukan tekanan para pihak. Sehingga tak heran jika Carl Friedrich mendefinisikan kebijakan sebagai suatu tindakan yang mengarah pada tujuan yang diusulkan oleh seseorang, kelompok, atau pemerintah dalam lingkungan tertentu sehubungan dengan adanya hambatanhambatan tertentu seraya mencari peluang-peluang untuk mencapai tujuan tertentu ${ }^{118}$.

Policy ditawarkan oleh sebuah kontestan pemilu untuk membawa masyarakat kepada kehidupan yang lebih baik. Itu juga berarti,

116 Lihat Wahab, 1998.

117 Lihat Tim Simpul Demokrasi, 2006:165-166.

118 Dalam Indiahono, 2009:18. 
policy merupakan solusi dari berbagai persoalan yang dianggap sebagai biang yang menyebabkan kehidupan tidak atau belum membaik $^{119}$.

Fungsi pemerintahan pada dasarnya meliputi fungsi regulasi, fungsi pemberdayaan, dan fungsi pembangunan. Dari fungsi regulasi, pemerintah memiliki kepentingan untuk memproses kebijakan agar disetujui oleh legislatif. Dari kebijakan inilah pemerintah memerlukan kepercayaan dari masyarakat bahwa tindakan-tindakannya sangat bermanfaat bagi masyarakat, tindakantindakan pemerintah ini dalam rangka menjalankan fungsi pemberdayaan dan pembangunan. Semua tindakantindakan tersebut dapat menjadi kajian para ilmuwan yang berminat mendalami kebijakan. Tindakan pemerintah merupakan sesuatu yang empiris dikaji dengan aspek-aspek yang sifatnya teoritis, sehingga sinergi antara "arena" empiris dengan arena "teoritis" dapat mengembangkan kebijakan sebagai suatu ilmu yang dinamis. Kebijakan dapat dikaji mulai dari perumusan, pelaksanaan, sampai evaluasi dari sudut pandang administrasi dan politik. Dari sudut pandang inilah dapat dilihat apakah pemerintah membuat kebijakan dengan mengakomodasi rakyat atau pemilih. Pelibatan rakyat dalam pembuatan kebijakan akan membawa peneliti pada analisis demokratis tidaknya suatu pemerintahan. Uraian tersebut diringkas oleh Nelson seperti kutipan di bawah ini:

Untuk menjalankan fungsi pemerintahan, kebijakan publik terbagi ke dalam empat hal: sebuah kepentingan dalam pola sistem politik yang menyeluruh beserta prosesnya, sebuah kepercayaan bahwa konsekuensi aksi-aksi pemerintahan adalah penting, sebuah perjuangan untuk menghasilkan pengetahuan yang sangat berguna secara teoritis dan empiris, dan penanggulangan masalah-masalah demokrasi ${ }^{120}$.

Tidak terlepasnya kebijakan dari politik terlihat dari pendapat Bauer, yang dikutip oleh Wahab bahwa:

Konsep pembuatan kebijakan publik menurut Raymond Bauer, dalam tulisannya The Study of Policy Formation, memandang pembuatan kebijakan publik sebagai "the process of transformation which turn political inputs into political outputs" (proses pengalihragaman yang mengubah masukanmasukan politik menjadi keluaran politik) $)^{121}$. 
Dengan demikian, kebijakan publik ditinjau dari sisi demokrasi menganjurkan kalau kebijakan sebagai keluaran politik dibuat berdasarkan masukan dari berbagai kepentingan. Partai politik yang bermetamorfosis menjadi penguasa eksekutif, seperti bupati dan anggota legislatif, sebaiknya dapat menerjemahkan kepentingan orang banyak ke dalam berbagai kebijakan. Dalam tataran implementasi, kebijakan menjadi tidak terasing dari kehidupan masyarakat, karena apa yang diberlakukan telah mengakomodasi kepentingan publik.

Produk kebijakan publik yang merupakan bentuk pertama kebijakan publik, yaitu peraturan perundangan yang terkodifikasi secara formal dan legal $^{122}$ di Indonesia, meliputi:

a. Undang-undang Dasar Negara Republik Indonesia Tahun 1945;

b. Undang-undang/Peraturan Pemerintah Pengganti UndangUndang;

c. Peraturan Pemerintah;

d. Peraturan Presiden;

e. Peraturan Daerah.

Setiap peraturan dari tingkat Pusat hingga tingkat desa atau kelurahan adalah kebijakan publik, karena mereka adalah aparat publik yang dibayar oleh uang publik melalui pajak dan penerimaan negara lainnya, dan karenanya secara hukum formal bertanggung-jawab kepada publik.

Jadi rentetan kebijakan publik sangat banyak, namun demikian secara sederhana dapat dikelompokkan menjadi tiga, yaitu:

1. Kebijakan publik yang bersifat makro atau umum, atau mendasar, yaitu kelima peraturan yang telah disebut di atas.

2. Kebijakan publik yang bersifat messo atau menengah, atau penjelas pelaksanaan. Kebijakan ini dapat berbentuk Peraturan Menteri, Surat Edaran Menteri, Peraturan Gubernur, Peraturan Bupati, dan Peraturan Walikota. Kebijakannya dapat pula berbentuk Surat Keputusan Bersama atau SKB antar-menteri, gubernur, dan bupati atau walikota.

3. Kebijakan publik yang bersifat mikro adalah kebijakan yang mengatur pelaksanaan atau implementasi kebijakan di atasnya. Bentuk kebijakannya adalah peraturan yang dikeluarkan oleh aparat publik di bawah menteri, gubernur, bupati, dan walikota.

Nugroho selanjutnya menyatakan, bentuk kebijakan publik pada umumnya terkodifikasi, namun menurutnya pernyataan-pernyataan lisan pejabat publik juga merupakan salah satu bentuk kebijakan publik. Dengan

122 Lihat Nugroho, 2008: 61-62.

344 CosmoGov, Vol.1 No.2, Oktober 2015 
demikian, bentuk kedua kebijakan publik adalah pernyataan pejabat publik $^{123}$.

\section{METODE PENELITIAN}

Metode penelitian yang digunakan adalah metode deskriptif dengan jenis studi kasus dan menggunakan pendekatan kualitatif. Metode deskriptif "dirancang untuk mengumpulkan informasi tentang keadaan nyata sekarang (sementara berlangsung)"124. Creswell ${ }^{125}$, yang mengutip pendapat Stake (1995), menyebutkan bahwa studi kasus sebagai salah satu strategi dalam penelitian kualitatif, yaitu:

Studi kasus merupakan strategi penelitian dimana di dalamnya peneliti menyelidiki secara cermat suatu program, peristiwa, aktivitas, proses atau sekelompok individu. Kasus-kasus dibatasi oleh waktu dan aktivitas, dan peneliti mengumpulkan informasi secara lengkap dengan menggunakan berbagai prosedur pengumpulan data berdasarkan waktu yang telah ditentukan.

Studi kasus yang dimaksud dalam penelitian ini lebih sesuai dengan kutipan dari Creswell tersebut.
Selanjutnya, menurut Denzin dan Lincoln ${ }^{126}$, kata kualitatif sukar diukur, namun penelitian ini menekankan realita secara sosial:

Kata kualitatif menyiratkan penekanan pada kualitas entitas, proses dan makna yang tidak dikaji atau diukur (jika memang diukur) secara eksperimental dari sisi kuantitas, jumlah, intensitas, atau frekuensi. Para peneliti kualitatif menekankan sifat realita yang terbangun secara sosial, hubungan erat antara peneliti dengan subjek yang diteliti, dan kendala situasional yang membentuk penelitian.

Dalam hal ini peneliti melihat realita yang terbangun antara partai pemenang pemilukada tahun 2010, yaitu Golkar, dengan jajaran eksekutif (pemerintah Kabupaten Bandung) dan legislatif (anggota DPRD Kabupaten Bandung periode 2009-2014) ketika menghasilkan kebijakan. Dalam melihat realita tersebut penelitian ini tidak lepas dari ciri-ciri yang dikemukakan oleh Finlay, yang dikutip Qudsy ${ }^{127}$, yaitu:

1. Peneliti akan secara langsung untuk berada di dalam setting penelitian; dalam hal ini peneliti akan mewawancarai para informan untuk mengumpulkan

123 Ibid Nugroho, hal. 63.

124 Lihat Sevilla, dkk., 1993:71.

125 Lihat Creswell, 2012:20.

126 Lihat Denzin dan Lincoln, 2011:11.

127 Lihat Qudsy, 2011:xviii. 
data. Selanjutnya data akan dipilih atau direduksi untuk menentukan data mana yang akan dipakai dalam analisis dan data mana yang dibuang. Setelah kegiatan ini dilakukan, data akan diinterpretasi untuk menghasilkan jawaban atas pertanyaan penelitian. Dalam tahap inililah pengetahuan baru diharapkan akan terungkap, yaitu berupa ada tidaknya konsistensi program partai politik pemenang pemilukada dengan produk kebijakannya.

2. Berusaha membangun hubungan yang baik dengan objek penelitian, yaitu Dewan Pimpinan Cabang Golkar Kabupaten Bandung, Bupati/Wakil Bupati Kabupaten Bandung periode 2010-2015, Lembaga Swadaya Masyarakat, anggota DPRD Kabupaten Bandung periode 2009-2014 dari Fraksi Golkar, jajaran birokrasi Kabupaten Bandung dan masyarakat yang merasakan kebijakan Bupati/Wakil Bupati. Dari hasil wawancara dengan mereka diharapkan interpretasi data ini dapat memudahkan pembaca untuk memahami alur pemikiran peneliti.

3. Peneliti akan menginvestigasi dan memahami apakah konsisten atau tidak untuk menghasilkan kebijakan sesuai dengan program partai ketika kampanye. Bila konsisten apa yang menjadi faktor pendukung; sebaliknya bila tidak, apa yang menjadi faktor penghambat. Tidak menutup kemungkinan akan ada hal-hal yang terjadi diluar dugaan peneliti, maka akan dicari pula mengapa hal tersebut terjadi dan bagaimana bisa terjadi akan diungkap dalam penelitian ini.

4. Fenomena yang disampaikan oleh informan akan diinterpretasikan sesuai dengan kapasistas informan sebagai pelaku atau terlibat dalam pembuatan dan pelaksanaan kebijakan. Kemudahan atau kesulitan dalam pembuatan dan pelaksanaan kebijakan akan peneliti ungkap pula melalui wawancara yang mendalam.

5. Peneliti akan berusaha untuk menyajikan hasil penelitian ini secara rinci dan komprehensif, meskipun temuan penelitian diprediksi akan kompleks. Dengan kata lain ada penyederhanaan hasil penelitian meskipun terdapat kompleksitas data di lapangan.

Untuk menghadapi kompleksitas data di lapangan, maka peneliti telah menggunakan teknik pengumpulan data yang akan diuraikan di bawah ini.

\section{Teknik Pengumpulan Data}

Menurut
Rossman $^{128}$, Marshall dan
metode dasar dalam


mengumpulkan informasi dalam penelitian kualitatifadalah:(1) participation in the setting, (2) direct observation, (3) in-depth interviewing, and (4) document review. Teknik pengumpulan data atau metode dasar yang dipilih oleh peneliti adalah nomor 3 dan 4 . Indepth interviewing, diartikan oleh Kahn dan Cannell, sebagai " $a$ conversation with a purpose". Peneliti menggali topik-topik yang ingin diketahuinya dari perspektif tertentu. Document review akan dilakukan dengan cara mengumpulkan dan menganalisis produk-produk kebijakan yang dikeluarkan oleh Bupati sebagai pemenang pemilukada. Kedua teknik tersebut dipilih karena in-depth interviewing membantu peneliti untuk mengeksplor informasi dari para nara sumber sebagai aktor yang terlibat dalam pembuatan dan pelaksanaan kebijakan, sedangkan document review akan membantu peneliti untuk melengkapi data primer dari para nara sumber. Dokumen yang dimaksud bisa berupa Peraturan Daerah, Peraturan Bupati ataupun Surat Keputusan Bupati. Dengan demikian peneliti akan menggunakan teknik triangulasi dalam memvalidasi data. Validasi data tentunya dilakukan sebelum menganalisis data.

\section{HASIL DAN PEMBAHASAN}

Sebelum membahas konsistensi antara program partai dengan produk kebijakan, peneliti akan melihat visi misi bupati terpilih dan produk kebijakan yang dihasilkan. Produk kebijakan yang dimaksud, peneliti batasi hanya Peraturan daerah dan Peraturan Bupati.

\section{Visi Misi Bupati Saat Pemilihan pada Tahun 2010}

Nugroho (2008) menyatakan bahwa misi adalah, yang pertama, karena melekat pada organisasi. Misi adalah raison d'etre, atau alasan mengapa organisasi hadir. Jadi, misi menentukan ke mana akan pergi. Jika misi melekat pada organisasi, dan tidak berubah selama organisasi ada, kecuali jika organisasi dirombak atau direformasi. Visi melekat pada individu yang memimpin organisasi. Setiap pemimpin organisasi harus mempunyai visi ke mana organisasi dibawa selama dibawah kepemimpinannya.

Dengan mengacu pada uraian di atas, realitas dalam organisasi pemerintahan justru sebaliknya. Misi organisasi pemerintahan Kabupaten Bandung berubah-rubah sesuai dengan kepala daerah terpilih. Untuk melihat perubahan tersebut, berikut peneliti sampaikan misi Pemerintahan Kabupaten Bandung periode 20052010. Misi Pemerintahan Kabupaten Bandung dengan Bupati Obar Sobarna, berdasarkan Rencana Pembangunan Jangka Menengah Daerah (RPJMD) 2005-2010, meliputi:

1. Mewujudkan Kepemerintahan yang baik; 
2. Memelihara Stabilitas Kehidupan Masyarakat yang Aman, Tertib, Tenteram, dan Dinamis;

3. Meningkatkan Kualitas Sumber Daya Manusia;

4. Meningkatkan Kesejahteraan Sosial Ekonomi Masyarakat;

5. Mamantapkan Kesalehan Sosial Berlandaskan Iman dan Taqwa;

6. Menggali dan Menumbuhkembangkan Budaya Sunda;

7. Memelihara Keseimbangan Lingkungan dan Pembangunan Berkelanjutan;

8. Meningkatkan Kinerja Pembangunan Desa.

Sedangkan misi Pemerintahan Kabupaten Bandung periode 20112015, adalah sebagai berikut:

1. Memantapkan Reformasi Birokrasi;

2. Meningkatkan Partisipasi Sektor Swasta dan Masyarakat dalam Pembangunan;

3. Meningkatkan Kualitas Sumber Daya Manusia;

4. Meningkatkan Pemberdayaan Ekonomi Kerakyatan dan Daya Saing Daerah;

5. Meningkatkan Ketersediaan dan Kualitas Infrastruktur serta Keterpaduan Pemanfaatan Ruang Kota;

6. Pemantapan Pembangunan Perdesaan;

7. Memantapkan Kesalehan Sosial Berlandasan Iman dan Taqwa;

8. Menggali, Menumbuhkembangkan, dan Melestarikan Budaya
Sunda serta Kearifan Lokal Lainnya;

9. Memantapkan Pemulihan Keseimbangan Lingkungan dan Pembangunan Berkelanjutan.

Ketika peneliti bandingkan kedua misi tersebut, maka ada perubahan dan penambahan di misi pemerintahan periode 2011-2015. Dengan kata lain, Partai Golkar yang mengusung Bupati Dadang M. Naser untuk periode 20112015 sebenarnya hanya memiliki 1 misi, yaitu misi kedua: "Memelihara Stabilitas Kehidupan Masyarakat yang Aman, Tertib, Tenteram, dan Dinamis". Misi pertama, ketiga, dan keempat Obar Sobarna (OS) sama dengan misi pertama, ketiga, dan keempat Dadang Naser (DN). Misi kelima OS sama dengan misi ketujuh DN. Misi keenam OS sama dengan misi kedelapan DN. Misi ketujuh OS sama dengan misi kesembilan DN. Misi kedelapan OS sama dengan misi keenam DN. Obar Sobarna yang merupakan Bupati Kabupaten Bandung periode 20052010 juga diusung oleh partai Golkar. Bila mengacu pada pendapat Nugroho, maka misi sebaiknya tidak berubah baik dari susunan maupun redaksional, karena misi adalah melekat pada Pemerintahan Kabupaten Bandung, siapa pun bupatinya.

Kalau misi sebetulnya tidak berubah selama organisasi ada, maka visi yang merupakan pandangan individual pemimpin dapat berubahrubah. Pada umumnya misi diterjemahkan sebagai turunan dari visi. Visi yang melekat pada diri Obar 
Sobarna sebagai pemimpin Kabupaten Bandung periode 2005-2010 adalah:

"Terwujudnya Masyarakat Kabupaten Bandung yang Repeh Rapih Kertaraharja, melalui Akselerasi Pembangunan Partisipatif yang Berbasis Religius, Kultural, dan Berwawasan Lingkungan, dengan Berorientasi pada Peningkatan Kinerja Pembangunan Desa."

Sedangkan, visi dari diri Dadang Naser sebagai pemimpin Kabupaten Bandung periode 2011-2015 adalah:

"Terwujudnya Kabupaten Bandung yang Maju, Mandiri, dan Berdaya Saing, melalui Tata Kelola Pemerintahan yang Baik dan Pemantapan Pembangunan Desa, Berlandaskan Religius, Kultural, dan Berwawasan Lingkungan."

Kedua visi tersebut telah menggambarkan pandangan dari masingmasing pemimpin, meskipun masih mempunyai kesamaan dalam hal religius, kultural, pembangunan desa, dan wawasan lingkungan. Perbedaan pandangan kedua pemimpin tersebut hanyalah pada tataran redaksional bukan pada substansi.

\section{Produk Kebijakan 2011-2015}

Produk kebijakan dalam penelitian ini meliputi Peraturan Daerah dan Peraturan Bupati Kabupaten Bandung selama lima (5) tahun atau satu periode masa jabatan bupati. Sampai tulisan ini dibuat, sampai tahun 2014 terdapat 94 Peraturan Daerah yang dibuat oleh Pemerintah Daerah Kabupaten Bandung, dengan rincian: tahun 2011 terdapat 23 Peraturan Daerah, tahun 2012 terdapat 30 Peraturan Daerah, tahun 2013 terdapat 19 Peraturan Daerah, dan tahun 2014 terdapat 22 Peraturan Daerah. Agar terlihat fluktuasi produk kebijakan ${ }^{129}$ tersebut, peneliti membuat tabel sebagai berikut:

Tabel 1

Produk Kebijakan berupa

Perda 2011-2015

\begin{tabular}{|c|c|c|}
\hline No & Tahun & Jumlah Perda \\
\hline 1 & 2011 & 23 \\
\hline 2 & 2012 & 30 \\
\hline 3 & 2013 & 19 \\
\hline 4 & 2014 & 22 \\
\hline 5 & 2015 & 5 \\
\hline Jumlah & & 99 \\
\hline
\end{tabular}

Sumber: Bagian Hukum, Sekretariat Daerah Kabupaten Bandung, diolah peneliti, 2015.

Sedangkan untuk Peraturan Bupati, sampai tahun 2015, terdapat 242, dengan rincian: tahun 2011 terdapat 71 Peraturan Bupati, tahun 2012 terdapat 58 Peraturan Bupati, tahun 2013 terdapat 63 Peraturan Bupati, tahun 2014 terdapat 36

129 Data-data dalam tabel dalam tulisan ini diperoleh peneliti selain dari Biro Hukum juga dari www.jdih.bandungkab.go.id. 
Peraturan Bupati, dan tahun 2015 terdapat 14 Peraturan Bupati. Untuk lebih jelasnya, produk kebijakan berupa Peraturan Bupati dapat dilihat dalam tabel di bawah ini:

Tabel 2

Produk Kebijakan berupa Perbup 2011-2015

\begin{tabular}{|c|c|c|}
\hline No & Tahun & Jumlah Perbup \\
\hline 1 & 2011 & 71 \\
\hline 2 & 2012 & 58 \\
\hline 3 & 2013 & 63 \\
\hline 4 & 2014 & 36 \\
\hline 5 & 2015 & 14 \\
\hline \multicolumn{2}{|c|}{ Jumlah } & $\mathbf{2 4 2}$ \\
\hline
\end{tabular}

Sumber: Bagian Hukum, Sekretariat Daerah Kabupaten Bandung, diolah peneliti, 2015.

\section{Konsistensi antara Program Partai Politik dengan Produk Kebijakan Publik}

Di tahun 2011, kebijakan yang sesuai dengan visi misi bupati sudah mulai tampak seperti Perda Nomor 12 tentang Perizinan Industri di Kabupaten Bandung yang sesuai dengan misi 1, yaitu Strategi Kebijakan Memantapkan Reformasi Birokrasi. Peneliti memasukkan ini sebagai usaha untuk mencapai reformasi birokrasi, karena Perda ini bertujuan menciptakan kesejahteraan masyarakat, pemerintah daerah harus memberikan pelayanan secara maksimal terhadap pertumbuhan dan perkem- bangan industri. Perda-perda yang lainnya sesuai dengan visi misi, kecuali Perda Nomorl tentang Pajak Daerah, Perda Nomor 2 tentang Perubahan Ketiga atas Peraturan Daerah Kabupaten Bandung Nomor 23 Tahun 2007 tentang Pembentukan Dana Cadangan untuk Pembebasan Lahan untuk Pembangunan Jalan dan Perda Nomor 3 tentang Perubahan atas Peraturan Daerah Kabupaten Bandung Nomor 17 Tahun 2006 tentang Perubahan Anggaran Pendapatan dan Belanja Daerah Kabupaten Bandung Tahun Anggaran 2006. Ketiga Perda tersebut bersifat internal untuk kepentingan jalannya roda pemerintahan.

Di tahun 2011 terdapat 3 Perda, tahun 2012 ada 8 Perda, tahun 2013 terdapat 2 Perda, dan tahun 2014 hanya 1 Perda yang sesuai dengan misi pertama, yaitu Kebijakan Memantapkan Reformasi Birokrasi.

Untuk selanjutnya, konsistensi antara program partai politik dengan produk kebijakan akan diuraikan di bawah ini.

Dalam penelitian ini ditemukan Peraturan Daerah (Perda) yang diturunkan kedalam Perbup dan langsung berkaitan dengan visi misi Golkar. Strategi kebijakan untuk reformasi birokrasi masih terlihat prosedural formal, artinya hanya terbatas perizinan usaha dan investasi, administrasi kependudukan, pelimpahan kewenangan dari bupati kepada camat, dan layanan informasi publik. 
Layanan yang bersentuhan langsung dengan masyarakat sampai dengan 2013 hanya terdapat satu produk kebijakan, yaitu Peraturan Bupati Nomor 32 Tahun 2011 tentang Standar Pelayanan Minimal (SPM) Bidang Kesehatan di Lingkungan Pemerintah Kabupaten Bandung, tetapi di tahun 2014 terdapat 11 produk kebijakan berupa Perbup. Sedang misi kedua, yaitu Startegi Kebijakan Meningkatkan Partisipasi Sektor Swasta dan Masyarakat dalam Pembangunan, hanya sebatas partisipasi masyarakat dalam membayar retribusi, sampai dengan tahun 2015 hanya satu Perda yang melibatkan partisipasi masyarakat, yaitu Peraturan Daerah Nomor 12 Tahun 2013 tentang Partisipasi Masyarakat dan Keterbukaan Informasi Publik dalam Penyelenggaraan Pemerintahan di Kabupaten Bandung.

Strategi Kebijakan Meningkatkan Kualitas Sumber Daya Manusia yang merupakan misi ketiga mulai menyentuh kepentingan masyarakat, yaitu bidang kesehatan, pembangunan kepemudaan, peningkatan kesejahteraan sosial, Pencegahan dan Penanganan Korban Perdagangan Orang, jaminan persalinan bagi yang tidak mampu, penanganan HIV, dan pendidikan. Misi keempat, yaitu Strategi Kebijakan Meningkatkan Pemberdayaan Ekonomi Kerakyatan dan Daya Saing Daerah, baru sebatas penyertaan modal kepada Badan Usaha Milik Daerah, sampai tahun 2015 belum bersentuhan langsung dengan pemberdayaan ekonomi di level masyarakat. Begitu juga dengan Strategi Kebijakan Meningkatkan Ketersediaan dan Kualitas Infrastruktur, serta Keterpaduan Pemanfaatan Ruang Kota yang merupakan misi kelima, pada umumnya masih berupa regulasi untuk pengembang, sedangkan peningkatan kualitas infrastruktur belum terlihat.

Misi keenam, yaitu Strategi Kebijakan Memantapkan Pembangunan Perdesaan, sampai dengan 2013 yang berkaitan langsung dengan masyarakat desa hanya direspon dengan satu produk kebijakan, yaitu adanya pedoman pengelolaan bantuan keuangan kepada Pemerintah Desa melalui Program Penguatan Pembangunan Perdesaan (P4), begitu juga dengan tahun 2014.di tahun tersebut misi keenam ini direspon dengan Peraturan Bupati Nomor 31 Tahun 2014 tentang Pedoman Pelaksanaan Program Penguatan Pembangunan Perdesaan di Kabupaten Bandung.

Misi ketujuh, yaitu Strategi Kebijakan Memantapkan Kesalehan Sosial berdasarkan Iman dan Taqwa, baru direspon pada tahun 2014 oleh dua kebijakan publik Peraturan Bupati. Strategi Kebijakan Menggali, Menumbuhkembangkan dan Melestarikan Budaya Sunda serta Kearifan Lokal lainnya yang merupakan misi kedelapan, sampai tahun 2015 hanya diwujudkan ke dalam satu Peraturan Bupati dengan menerapkan Kurikulum Muatan Lokal Sejarah dan Budaya 
Kabupaten Bandung di lingkungan persekolahan. Terakhir, misi kesembilan, yaitu Strategi Kebijakan Memantapkan Pemulihan Keseimbangan Lingkungan dan Pembangunan Berkelanjutan, merupakan program partai yang banyak direspon oleh produk kebijakan. Sampai tahun 2015, 11 kebijakan tentang keseimbangan lingkungan telah dikeluarkan.

\section{KESIMPULAN DAN SARAN}

\section{Kesimpulan}

1. Terdapat perbedaan dalam menerjemahkan Visi dan Misi Bupati Kabupaten Bandung 2015. Misi dianggap merupakan turunan dari visi, padahal misi tidak dapat berubah-rubah siapa pun bupatinya, selama organisasi itu ada. Sebagai perbandingan, misi Bupati Kabupaten Bandung periode 2005-2010, sedikit berbeda dengan misi Bupati Kabupaten Bandung periode 2011-2015. Sebaliknya visi yang merupakan pandangan individual, memiliki substansi yang sama dengan Bupati sebelumnya.

2. Produk kebijakan berupa Perda lebih sedikit dibanding Perbup. Kedua produk kebijakan ini sebagian besar merupakan respon dari Undang-undang atau Peraturan dari Pemerintah Pusat, atau merupakan aturan internal untuk kegiatan Pemerintah Daerah. Produk kebijakan yang secara eksplisit menyebutkan berkaitan dengan visi misi hanya satu.

3. Semua misi sudah konsisten dengan produk kebijakan, meskipun dalam kuantitas banyak perbedaan, antara misi yang satu dengan yang lainnya. Selama masa periode 2011-2015 terdapat dua misi yang direspon tidak lebih dari dua produk kebijakan.

\section{Saran}

1. Misi partai politik yang dibuat sebaiknya dibuat operasional, artinya ketika diturunkan kedalam kebijakan pemerintahan dapat direalisasikan.

2. Produk-produk kebijakan sebaiknya mementingkan kepentingan masyarakat atau yang langsung berkaitan dengan masyarakat, sehingga masyarakat dapat merasakan manfaat adanya pemimpin dan dapat merasakan bahwa pilkada bermanfaat sebagai sarana untuk berpartisipasi dalam menentukan kebijakan publik.

3. Agar terjadi konsistensi antara program partai dengan produk kebijakan, sebaiknya ada instansi-apakah swasta atau pemerintah-yang memonitor kebijakan-kebijakan yang dikeluarkan selama kepala daerah memerintah. Dengan demikian dapat diminimalisir program atau kebijakan yang menyimpang dari visi misi bupati terpilih. 


\section{DAFTAR PUSTAKA}

Creswell, John W., 2012. Research Design: Pendekatan Kualitatif, Kuantitatif, dan Mixed. Edisi Ketiga. (Penerjemah: Achmad Fawaid). Yogyakarta: Pustaka Pelajar.

Denzin, Norman K. dan Yvona S. Lincoln, 2011. Disiplin dan Praktek Penelitian Kualitatif, dalam Denzin, Norman K. dan Yvona S. Lincoln (Ed). The Sage Handbook of Qualitative Research. Edisi Ketiga. (Penerjemah: Daryatno). Yogyakarta: Pustaka Pelajar.

Indiahono, Dwiyanto, 2009. Kebijakan Publik: Berbasis Dynamic Policy Analysis, Yogyakarta: Gava Media.

Klinaemann, dkk., 2000. Partai, Kebijakan \& Demokrasi (Penerjemah: Sigit Jatmika), Yogyakarta: Pustaka Pelajar.

Marshall, Catherine and Gretchen B. Rossman, 1995. Designing Qualitative Research (Second Edition). California: Sage Publication Inc.

Nelson, Barbara J. Public Policy and Administration, dalam Robert E. Goodin dan Hans Dieter Klingemann (ed). 1996. A New Handbook of Political Science. New York: Oxford University Press Inc.

Niemi, G. Richard dan Herbert F. Weisberg, 1984. Controversies in Voting Behavior. Washington: Congressional Quarterly Inc.
Nursal, Adman, 2004. Political Marketing: Strategi Memenangkan Pemilu, Sebuah Pendekatan Baru Kampanye Pemilihan DPR, DPD, Presiden. Jakarta: PT. Gramedia Pustaka Utama.

Nugroho, Riant, 2008. Public Policy. Jakarta: PT. Gramedia.

Pamungkas, Sigit, 2011. Partai Politik: Teori dan Praktik di Indonesia. Yogyakarta: Institute for Democracy and Welfarism.

Santoso, Purwo, 2010. Modul Pembelajaran Analisis Kebijakan Publik. Yogyakarta: PolGov.

Sevilla, dkk., 1993. Pengantar Metode Penelitian. Jakarta: UI Press.

Tim Penyusun Demokrasi, 2006. Reformasi Birokrasi dan Demokratisasi Kebijakan Publik. Malang: Averroes Press.

Wahab, Solichin Abdul, 2008. Pengantar Analisis Kebijakan Publik, Malang: UMM Press.

Qudsy, Saifudin Zuhri, 2011. Pengantar: Bayang-bayang Agenda Revolusioner Penelitian Kualitatif. dalam Denzin, Norman K. dan Yvona S. Lincoln (Ed). The Sage Handbook of Qualitative Research. Edisi Ketiga. (Penerjemah: Daryatno). Yogyakarta: Pustaka Pelajar.

Peraturan Perundang-undangan:

Peraturan Daerah Kabupaten Bandung Tahun 2011, 2012, 2013, 2014, dan 2015.

Peraturan Bupati Kabupaten Bandung Tahun 2011, 2012, 2013, 2014, dan 2015. 